\title{
PRESENTATION, THE BEST MODEL FOR TEACHING SPEAKING FOR ADULTS STUDENTS
}

\author{
S M. Budiyanto, Sigit Haryanto \\ FKIP- Universitas Muhammadiyah Surakarta, Central Java, Indonesia \\ Email:smb202@ums.ac.id/Mobile: 08562818721
}

\begin{abstract}
The aim of the research is to show that presentation is one of the best models for teaching speaking for Adult students. This research and development study consists of exploration, designing model draft, validating model, experts jugment, revising model, implementing model, data description, data analysis, findings and discussion, recommendation, revising, the final model and dissemination. Technique of data collection was obtained by using test, interview, and observation; Technique of data analyze for quantitative data used non independent t-test. The researcher also used descriptive statistic including highest, average, and lowest scores. To analyze the qualitative data, the researcher used trianggulation and flow model of analysis. The research results showed that The first model results showed that: it improved the students' bravery to speak up in front of the audience and made a better condition of the students'speaking environment. The second model results showed that the development of the students'speaking ability growing up rapidly and their grammar and vocabulary also getting better. The Final Model results showed that there is very clear improvement on their bravery to speak up in front of the audience. Their learning progress and speaking ability grew up rapidly, their grammar and vocabulary also increased significantly. The computation result showed that all of the results is higher than $t$ (2,02). It showed that Developing a model of teaching speaking through presentationis good, suitable and accurate for teaching and improving the Students' Speaking Ability of accounting education of UMS is proved correct and significant.
\end{abstract}

Keywords: adult;model; teaching; speaking; presentation

\section{Introduction}

English is the most important language in international communication nowadays. English is also language of science and knowledge, because most of the science and knowledge in the world are writing down in English. How can we understand the science and knowledge in the world, if we do not understand English at all? How can we communicate with the foreign people to run on our business or to make some agreement with them, if we can not speak English well? Because of its strategic and important role in business, international communication, science and technology, therefore, English is admitted to be the first foreign language to be taught in Indonesia.

The students of university should be recognized that no matter what the Program they come from, they should be able to speak English well. It is one of the requirements to compete for better and brighter future in themodern era with very tight competition in international business, job, career, and education.

Teaching speaking is very interesting and challenging, but it is hard job, therefore, it should be done by the lecturer/teacher seriously and carefully. Thewriter wants to develop presentation model for teaching speaking. 


\section{The Students' problems}

Nowadays, no matter what the department they come from, the students of university should be able to speak English well. Unfortunately, the speaking ability of university students is still low and unsatisfying. From pre-observation and need analysis, the researcher notes that they have many problems in speaking English. Based on the background of the study and all the explanation above, therefore, the researcher is able to identify some problems why their speaking ability is still low and unsatisfying, those are as follows;

1. The students lacked of spirit and motivation to study English

2. The students 'environment' did not support the speaking condition

3. The students felt ashamed, afraid, worried and nervous in speaking

4. The students have limited vocabularies and grammar.

As a result, they have low ability and difficulties in expressing ideas, desires, feelings or minds through speaking. On the other ways around, they were demanded to speak English well for their future job, in the business world and in international community. The reality in our environment and even in the world suggested that the university students should be able to speak English well. If not, they will be left behind in this modern era.

\section{The Students' opportunity}

As everyone knows, that speaking is the most important, challenging, and interesting skills of the four language aspects. Many people also realize and recognize that speaking is difficult enough to master, but the great effort should be done to achieve the best result that is "The ability to speak English well". By using presentation model, he hopes that it will be able to overcome the students' speaking problems.

If the students able to speak English well, they will get a better future for their career in job, business, and education. It is absolutely true that, the ability of speaking English well will give a lot of advantages, it is very important in our life, career, and in international business communication, even this ability will be appreciated by the other people and society. As the researcher had mention above that the ability of speaking English well is very important in our life, career, education, and in international business communication, even this ability will be appreciated by the other people and society. Therefore, the researcher finds out the best techniques and models for teaching speaking through "Developing the model of teaching speaking through presentation for accounting eduction students", It helps the students speaking's problems, in order to speak English well.

The wise statements suggested that "language is speaking and language is behavior, so, if you want to master it, you have to use it as often as possible". Thus, practicing is very important in learning English, because practice makes perfect, and fortunetely In presentation model the students practice a lot their speaking, because the rule in our language teaching in class that everybody should try to speak up in English, therefore, it supports the students's speaking ability, because the key words of mastering speaking is in "practicing", so more practicing makes speaking ability to be better.

\section{Model}

A small object, usually built to scale, that represents in detail another, often large object. A representative form or pattern. A prelimenary work or construction that serves as a plan from which a final product is to be made.(Margaret Rouse, 2011). Model is a systematic description of an object or phenomenon that shares important characteristics with the object or phenomenon. Scientific model can be material, visual, mathematical, or computational and are often used in the construction of scientific theories. 


\section{Teaching}

Teaching today involves making choices in design, development, implementation, and evaluation of instruction and assessment of learning outcomes. The definition of teaching is the act of profession of a person who teaches. Teaching is instruction (something that is taught and it is the profession of teacher/ lecturer), pedagogy is recognized as an important profession, precept, commandment, didactics, educational activity is (the activities of educating /instructing activities that impact knowledge or skill). Teaching is to cause to know something (taught them a trade) and to cause to know how (teaching someone to drive), to cause to know the disagreeable consequeces of some action and to accustom to some action or attitude (teach the students to think for themselves). Teaching is to conduct instruction regularly in, to guide the students of, to instruct by percept (examples/ experiences) and to impact the knowledge of (teaching English).

Synonym of to teach is instruct, educate, train, discipline, school mean to cause to aquire knowledge or skill. Teach applies to any manner of imparting information or skill so that others may learn (taught us a lot about our planet). Instruct suggests methodical or formal teaching. Educate implies development of the mind (more things than formal schooling serve to educate a person). Train stresses instruction and drill with a specific end in view (trained foreign pilot to operate the new aircraft), Discipline implies training in habits of order and precision (a disciplined mind), School implies training or disciplining especially in what is hard to master (schooled the horse in five gaits). Teaching is the act or business of instructing; also that which is taught; instruction.

Teaching includes all the activities of providing education to other. The person who provides education is called teacher. Teacher uses different method for giving the best knowledge to his students. He tries to do his best to make understand students. His duty is to encourage the students to learn the subjects seriously. Teaching means interactions of teacher and students. They participate for their mutual benefits. Both have their own objective and target is to achieve them. Many great teachers of world define teaching in different way and we can say that teaching is just to train the students so that they can stand on their own foot in the society. In teaching there are three main aspects come in our front (teacher, students, and education).

Teaching is profession of those who give instruction, especially in an elementary or secondary school or university. The teaching profession is a relatively new one. Traditionally, parents, elders, religious leaders, sages were responsible for teaching children how to behave and think and what to believe. Germany intruoduced the first formal criteria for the education of teachers in 18th century, in the 19th century, as society became more industrialized, the concept of schooling became more universal. In industrialized nations today, most teachers are university graduates. Teachers-training programs usually include both general and specialized academic, cultural, or vocational courses; the study of educational principles; a series of professional courses combined with practical experience in a typical school setting. Most countries also require professional certification following formal training.

Burns (2001) surveys the potential contribution to the pedagogy of speaking of systemic functional linguistics (SFL), exchange structure (IRF) analysis, CA, critical discourse analysis (CDA), and speech act theory and pragmatics. Teaching is the act of profession of a person who teaches. It is instruction, pedagogy is recognized as an important profession, precept, commandment, didactics, educational activity is the activities of educating that impact knowledge or skill.

\section{Speaking}

Speaking is "the process of building and sharing meaning through the use of verbal and non-verbal symbols, in a variety of contexts" (Chaney, 1998, p. 13). Speaking is a crucial 
part of second language learning and teaching. Despite its importance, for many years, teaching speaking has been undervalued and English language teachers have continued to teach speaking just as a repetition of drills or memorization of dialogues.

However, today's world requires that the goal of teaching speaking should improve students' communicative skills, because, only in that way, students can express themselves and learn how to follow the social and cultural rules appropriate in each communicative circumstance (Hayriye Kayi, 2013)

Goh provided five chapters to explain how teachers can provide structured and guided learning experiences for language learners to develop their speaking competence, each of which contains reflection tasks to encourage readers critical thinking, figures to explain the construct of speaking and present current research findings, and illustrated teaching activities and models. She: 1. Offered essential theoretical perspectives in considering speaking as process, skill, and product 2 Focused on fluency-oriented tasks for developing a range of speaking skills, 3 introduced an informed pedagogical model. 4. Highlighted recent research findings on spoken English and speaking performance by explaining the pedagogical relevance of spoken grammar, pre-task planning, and task repetition. 5. Stated that "Written in an accessible and friendly style, practical and technique-oriented, and focused on both principles and procedures this small but comprehensive booklet provides a very useful walk-through guide for readers who want to teach speaking more effectively and successfully in second language classroom". (Goh Christine. 2007. Teaching Speaking in the Language Classroom. Singapore: SEAMEO Regional Language Centre, 2007. Pp. ii +48 )

We should study and learn harder to understand, master and speak English well; because the main target of someone studied foreign language/English is to speak English well. We can understand the science and knowledge in the books, if we studied hard and seriously to understand English and always practice it as oftem as possible to make our speaking English better, because practice makes perfect. By speaking English well, so we can communicate with the foreign people easily. We can run on and conduct our international business or to make some agreement with them/foreign people smoothly. Mastering English/speaking well would give a lot of benefits for our better and brighter future. Because of its strategic, crucial and important role in education, business, politics, social, culture, technology science and knowledge, English is admitted to be the first foreign language to be taught in Indonesia.

Prof. Jayashree Mohanraj (2013 - Unity in Diversity in Non-Native Speakers' English) stated that "Twenty first century world is called a globalized village. Globalization is a great equalizer, at the same time it is a powerful divisive force. It brings out certain differences between linguistic, religious, and cultural groups. Therefore it can be dangerous and divisive unless handled with care. English is looked upon as a global language. Today, English is spoken by about 400 million native speakers. Of whom about 240 millions are Americans. The British, Irish, Australians, New Zealanders, Canadians and South Africans make up most of the others. There are about 1500 million who speak English as a second or foreign language. So, for every one native speaker there are three or four people in the world who speak English as speakers of 'other language' or as a non-native speaker.

The growth and popularity of English as a global language has been continuing for over a century. In the nineteenth century English was heralded from Europe to the Asian countries. By the end of the $20^{\text {th }}$ century, learning English has come to be seen as less of an option and more of an urgent economic need. As Graddol, David (2007) puts it, 'English learners are increasing in number and decreasing in age.' There are several statistics available about the foreigners using English. 
David Crystal's survey reveals that the number of other language speakers learning English is three times more than those who speak the language as their mother tongue. This also means that people belonging to several different mother tongues use English as a lingua franca. And, already we hear rumblings about 'English hegemony' 'killer language' that forces minority languages on the path of extinction. Hence English needs to be looked upon as 'fragile, handle with care' label so that it promotes 'unity in diversity' in the Non-Native Speaker (NNS) context. Diversity is a reality. Diversity is exciting. Diversity cannot be wished away. When two people come together seeds of diversity are sown. When native speakers of other languages speak English, English acquires a variety. In fact, even within the native speakers there is diversity.

The British, American, Australian Englishness do not sound the same. Within Great Britain Irish and Welsh have their distinct accents. Even within the countries where English is the mother tongue the texture of the population is changing. Those who speak English as a second language in the USA are thought to number around 12 percent of the total population and their number is increasing. David Crystal acknowledges, 'The notion of a generic native speaker has become so diversified that it has lost its meaning.' (ibid) So, non-native speakers of English need not be apologetic if they lend to further diversity. Further, the environment in which other speakers of English be it as second language or foreign language, learn English, makes it very difficult to attain native like competence. What is attainable and essential is intelligibility.

\section{Teaching Adults}

Why adult students? The reasons why did he choose adultstudents because he wants to prove that adult students will be able to speak English well, if they teach and train in good, accurate and suitable model, therefore by applying presentation model in a class, it will give the students special freedom to express their ideas, desires, and minds through speaking. Presentation is appropriate and suitable model for adult students and it has a lot of strength for improving the students speaking ability. By using Presentation, the students have a freedom in expressing ideas, minds, feeling and desire through speaking.

Although many of the rules for teaching children can apply in some ways to teaching adults, the latter age group poses some differents, special consideration for the classroom teacher. Adults have superior cognitive abilities that can render them more successful in certain classroom endeavors. Their need for sensory input can rely a little more in their imaginations Their level of shyness can be equal to or greater than that of children, but adult usually have acquired a self confidence not found in children. And, because of adults' cognitive abilities, they can at least occasionally deal with language that isn't embedded in "here and now" contect (Brown,Douglas.H. 2001, 90).

So, as you consider the five variables that apply to children, keep in mind some specific suggestions and caveats, such as:Adults are more able to handle abstract rules and concepts. But beware! Too much abstract generalization about usage and not enough real life language can be deadly for adult too.

Adults have longer attention spans for material that may not be intrinsicaly interesting to them. But again, the rule of keeping your activities short and sweet applies also to adult age teaching.Sensory input need not always be quite as varied with adults, but one of the secret of lively adults classes their appeal to multiple senses.Adults often bring a modicum of general self-confidence into a classroom: the fragility as critical as those of children. Yet we should never underestimate the emotional factors that maybe attendant to adult second language learning.

Adults, with their more developed abstract thinking ability: are better able to understand a contect-reduced segment of language. Authenticity and meaningfulness 
are of course still highly important, but in adults language teaching, a teacher can take temporary digression to dissect and examine isolated linguistics properties as long as students are returned to the original context (Brown,Douglas.H. 2001, 91).

\section{Things to avoid in teaching adults}

We have to do remember that though adults can not express complex thinking in the new language, they are nevertheles inteligent adults with mature cognition and emotion. Don't treat adults in your class like children by (calling them'kid', using 'caretaker' talk, talking down to them). We have to do give your students as many opportunities as possible to make choices what will they do in and out of the classroom. And donot dicipline adults in the same way as children.

\section{Presentation overall}

All presentations have a common objective. People give presentations because they want to communicate in order to: Inform, train, persuade, and sell. A successful presentation is one of the most effective ways of communicating your message. And because English is so widely used in international business, a working knowledge of the vocabulary and techniques used in an English language presentation is a valuable asset.

\section{Preparation}

Can you name the most important things when giving any presentation? Preparation! You will be totally confident and less nervous. And your audience will feel your confidence. Your audience, too, will be confident. They will be confident in you. And this will give you control. Control of your audience and of your presentation. With control, you will be 'in charge' and your audience will listen positively to your message.

\section{Objective}

Before you start to prepare a presentation, you should ask yourself: Do you need to inform, to persuade, to train or to sell?
Your objective should be clear in your mind. If it is not clear in your mind, it cannot possibly be clear to your audience.

\section{Audience}

Sometimes this will be obvious, but not always. You should try to inform yourself. How many people? Who are they? Business people? Professional people? Political people? Experts or non-experts? Will it be a small, intimate group of 4 colleagues or a large gathering of 400 competitors? How much do they know already and what will they expect from you?

\section{Venue}

In a small hotel meeting-room or a large conference hall? What facilities and equipment are available? What are the seating arrangements?

\section{Time and length}

The Time and length of presentation is crucial to know. Will it be in 25 minutes or 1 hour? In the morning, afternoon or evening, it should be clear.

\section{Method}

What kinds of approach you should use for your presentation? Formal or informal? Lots of visual aids or only a few? Will you include some anecdotes and humour for variety?

\section{Content}

Now you must decide exactly what you want to say. First, you should brainstorm your ideas. You will discover many ideas that you want to include in your presentation. But you must be selective. You should include only information that is relevant to your audience and your objective. You should exclude all other ideas. You also need to create a title for your presentation. The title will help you to focus on the subject. And you will prepare your visual aids, if you have decided to use them. But remember, in general, less is better than more. You can always give additional information during the questions after the presentation. 


\section{Structure}

A well organised presentation with a clear structure is easier for the audience to follow. It is therefore more effective.
You should organise the points you wish to make in a logical order. Most presentations are organised in three parts, followed by questions:

\begin{tabular}{|c|c|c|}
\hline Beginning & Sort introduction & $\begin{array}{l}\text { - welcome your audience } \\
\text { - introduce your subject } \\
\text { - explain the structure of your presentation } \\
\text { - explain rules for questions }\end{array}$ \\
\hline Middle & Body of presentation & - present the subject itself \\
\hline & Short conclusion & $\begin{array}{l}\text { - summarise your presentation } \\
\text { - thank your audience } \\
\text { - invite questions }\end{array}$ \\
\hline
\end{tabular}

\section{Notes}

When you give your presentation, you should beor appear to be as spontaneous as possible. You should not read your presentation! You should be so familiar with your subject and with the information that you want to deliver that you do not need to read a text. Reading a text is boring! Reading a text will make your audience go to sleep! By using notes, you can create your own system of notes. Some people make notes on small, A6 cards. Some people write down just the title of each section of their talk. Some people write down keywords to remind them.

\section{Rehearsal}

Rehearsal is a vital part of preparation. You should leave time to practise your presentation two or three times. This will have the following benefits:you will become more familiar with what you want to say andyou will identify weaknesses in your presentation. you will be able to practise difficult pronunciations and you will be able to check the time that your presentation takes and make any necessary modifications. So prepare everything: words, visual aids, timing, and equipment. 


\section{The Model Development: Figure 1: Model Development}

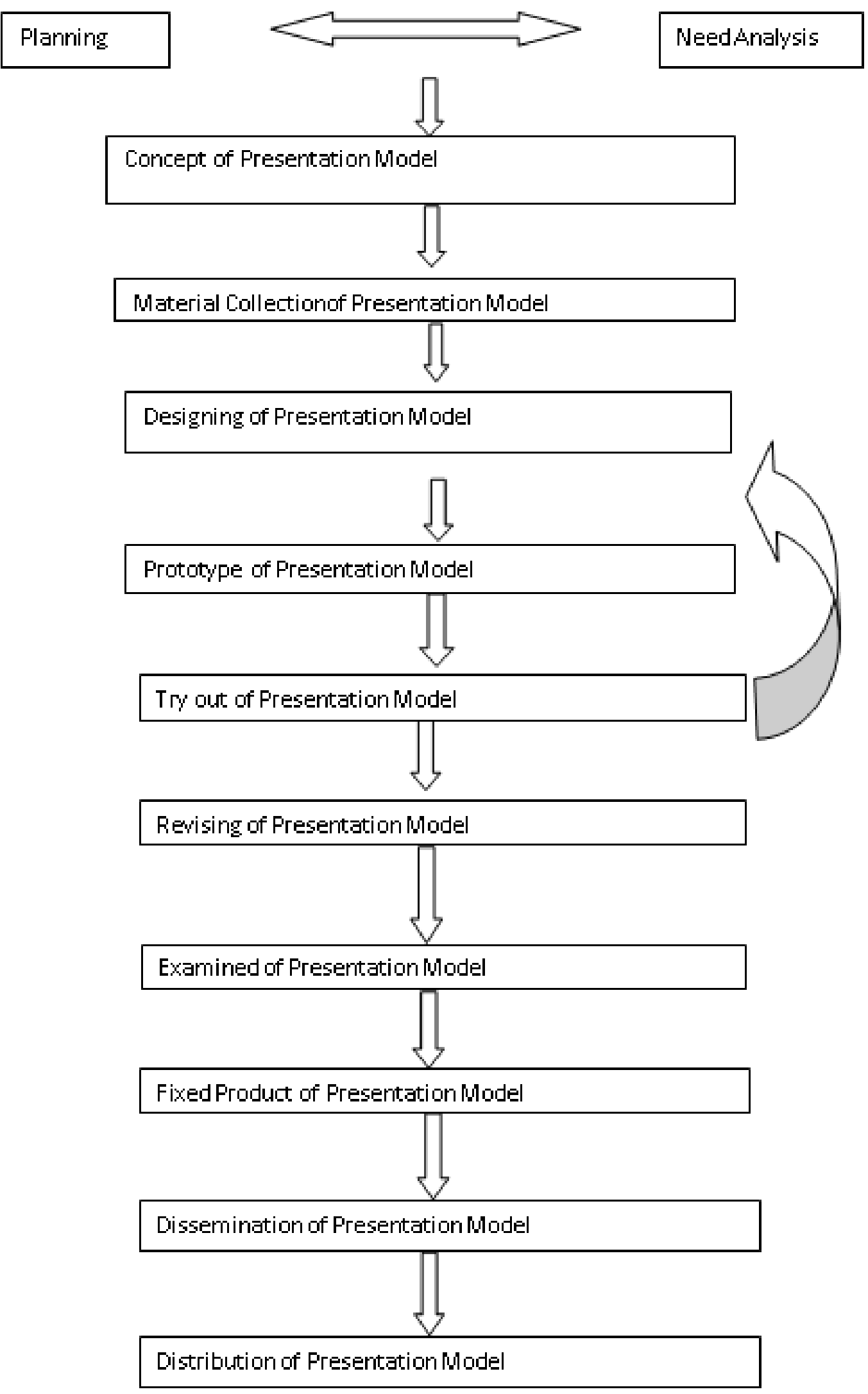




\section{The Research Development Procedures}

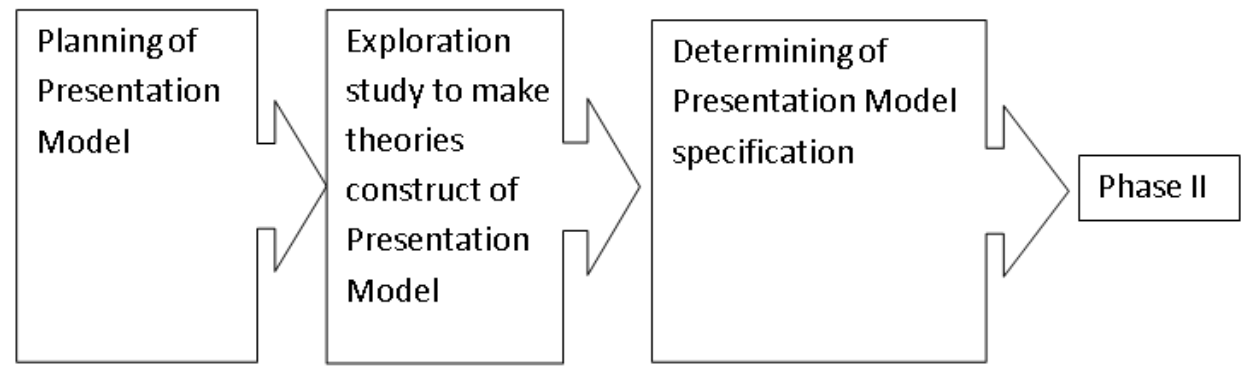

Figure 2 - Phase I - Pre Development of Presentation Model

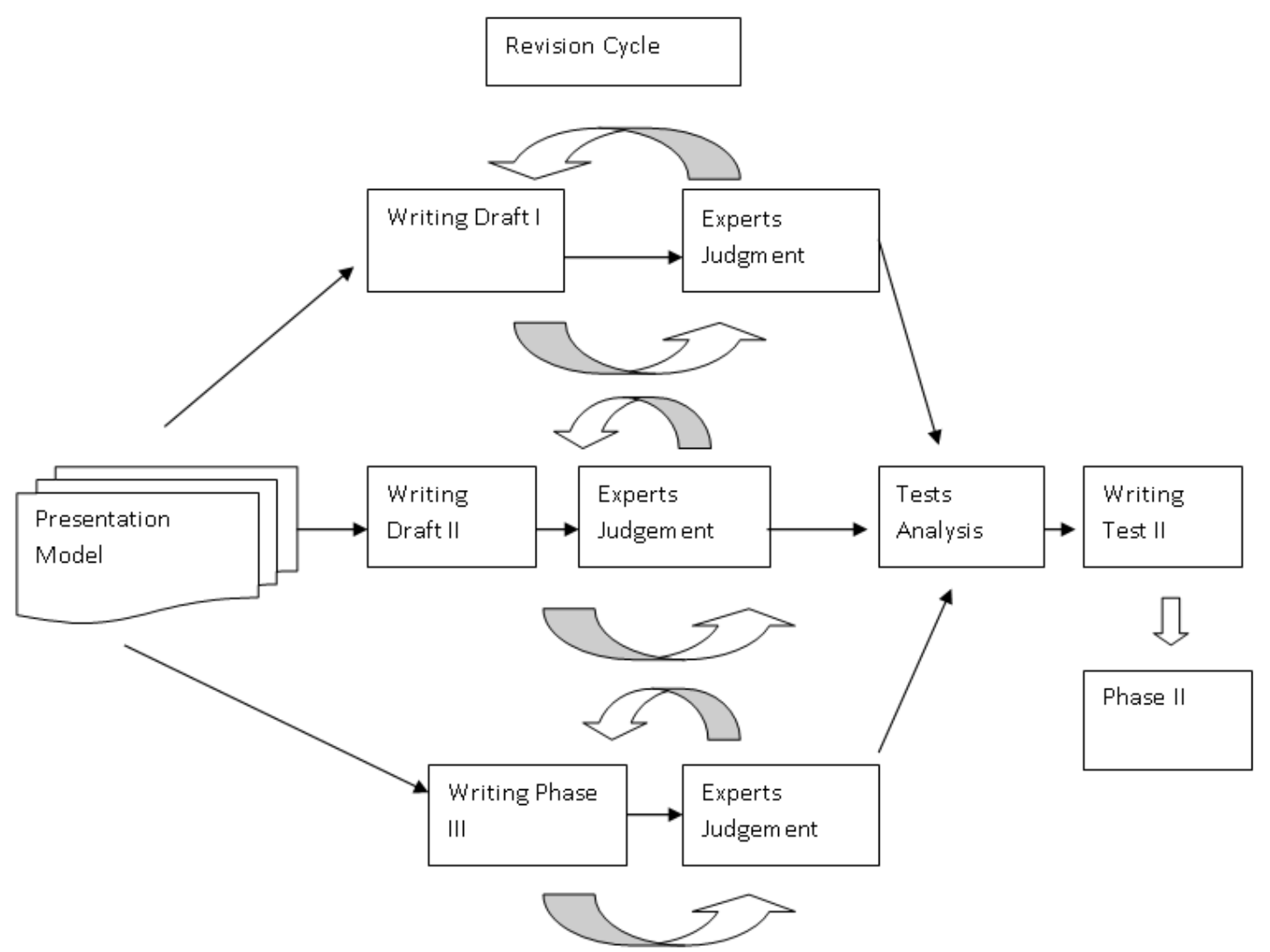

Figure 3 : Phase II Development of Presentation Model 


\section{Phase III - Implementation of Presentation Model figure 4}
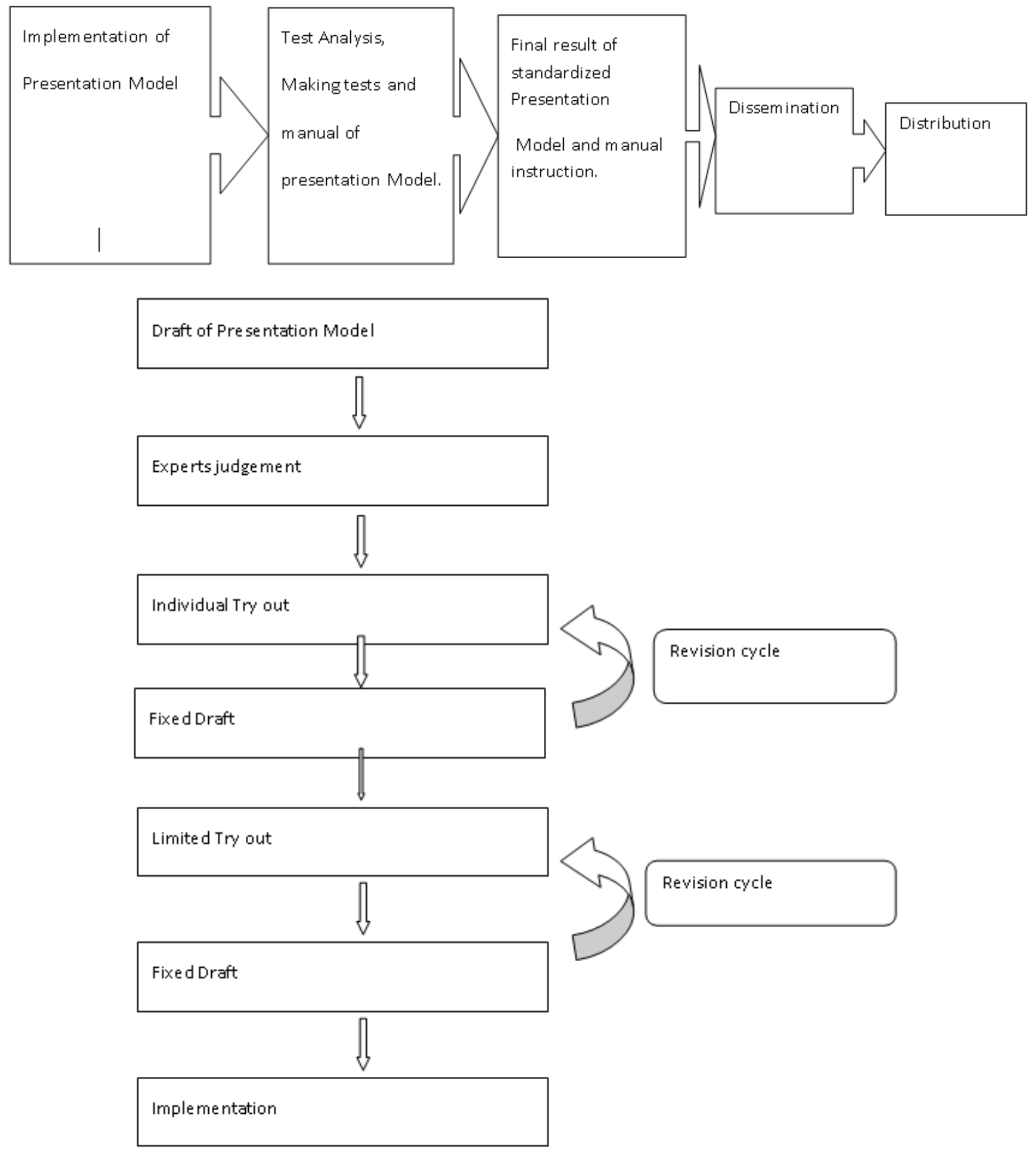

Figure 5: Try out DesignDraft of Discussion and Presentation Model 
Dissemination the Product of research that is

\section{The advantages of the Research}

There are many advantages of the research and it is very crucial for:

\section{Education}

This writing will give many advantages for enlarging and enriching the teaching speaking process and to know whether presentation is suitable or not with the condition of the students, because accurate and suitable model will give significant result in teaching speaking. And Presentation is one of good models for improving and increasing the students speaking ability, especially in adult class or university level.

\section{Teacher or Lecturers}

This writing will give teachers or lecturers a lot of choices for improving the teaching speaking process by selecting the suitable model, therefore, they can develop their creativity to improve the teaching speaking process. Since there are no best madels for teaching speaking, thus, it stimulates the teachers or lecturers to find out a model which is appropriate for teaching speaking. Besides, they have to be creative, careful, and smart in selecting the most suitable model that is in line with the condition of their students. This writing will give the teachers or lecturers a wider view and better ability for improving the condition of passive and silence class to be active and vivid class. The teachers or lecturers will prove that presentation model is a good model for improving the students speaking ability, especially for adult class or university level.

\section{Students/learners}

This writing will give them a lot of experiences for enlarging and enriching their knowledge about language, especially for their speaking ability because no matter what department they come from, the students of university should be able to speak English well.
Practicing and learning speaking by using Presentation model will give some benefits and advantages for improving the students speaking ability because this model gives them a lot of experiences and opportunity to practice their speaking freely through expressing their minds and ideas by speaking.

\section{Writer}

This writing will give him a valuable experience for gaining something better in his career and future. It will develop and enlarge his science and knowledge in language instruction and give him many choices for delivering an excellent service for his students in university, especially in teaching speaking. It will give him a wider view, strong belief and better motivation for increasing his innovation, creativity, science, knowledge and ability in teaching speaking.

\section{Conclusion}

Presentation model is appropriate and suitable for adult students and it has much strength for improving the students speaking ability. Presentation model helps students to practice a lot in their speaking. These model gives a lot of oppurtunity for students to explore and express their ability in speaking, It also gives them special freedom to express their minds, desires, feelings and ideas through speaking.

Presentation able to give a lot of chances for practicing, mastering and exploring the students' speaking ability. Therefore, the students get the bravery, spirit and motivation to practice their speaking in front of the class/ audience; the students be accustomed and forced to speak English, so they can overcome their own problems in expressing ideas, desires, minds and feeling through speaking. they do the best in speaking. The principles in presentation are easy to be understood by them, so they can apply it in a real situation.

Since there is no best models for teaching speaking in the world, thus, it stimulates the teachers or lecturers to find out a model which 
is appropriate for teaching speaking and suitable with the condition of the students. They have to be creative, careful, and smart in selecting the most suitable model that is in line with the condition of their students, especially for adult/university students. This research gave the teachers or lecturers a wider view, more experience and better situation for improving the students' speaking ability and to change the condition of passive and silence class to be active, happy and vivid class. The researcher prove that presentation is one of the best models for teaching speaking for adult/university students.

\section{Bibliography}

Brown Douglas, 2001 TEACHING by PRINCIPLES an Interactive Approach to Language Pedagogy, Second Edition, San Francisco State University

Burns, A. (2001) Teaching speaking. Annual Review of Applied Linguistics, 18, 102 - 123.

Carter, R. (1997). Speaking English, speaking cultures, using CANCODE. Prospect, 12, 4-11. Carter, R. (1998). Orders of reality: CANCODE, communication and culture. ELT Journal, 52, 43-56.

Chaney, AL and TL BURK (1998) Teaching Oral Communication in Grades K8 Boston:

Allyn \& Bacon

Crystal, D., (2003) English as a Global Language. Cambridge, Cambridge University Press.

CHRISTINE GOH. 2007. TEACHING SPEAKING IN THE LANGUAGE CLASSROOM. SINGAPORE: SEAMEO REGIONAL LANGUAGE CENTRE, 2007. PP. II + 48, REVIEWED BY ZENG YAJUN NATIONAL INSTITUTE OF EDUCATION, NAN YANG TECHNOLOGICAL UNIVERSITY SINGAPORE

Cunningham Florez, M. (1999). Improving adult English language learners'speaking skills. ERIC Digest, June 1999. (ED425304). National Center for ESL

Dale, P. Wolf C. J. Speech Communication Made Simple A. Multicultural Perspective, Second Edition Longman, Inc., all right reserved. Miami Dade. Community college

Hayriye Kayi. http://unr.edu/homepage/hayriyekkayih [at] unr.nevada.edu (TeachingSpeaking Activities to Promote Speaking in a Second Language - 2013) University of Nevada (Nevada, USA)

Mohanraj Jayashree Prof. (2013) Unity in Diversity in Non-Native Speakers' English, The English and Foreign Languages University - Hyderabad, India.

Richard, Jack C and Theodore S Rodgers, 2001, Approaches and Methods In Language Teaching, Second Edition, Cambridge University press 